ОСОБЛИВОСТІ ЕМОЦІЙНИХ СТАНІВ СТУДЕНТІВ НА СЕМІНАРСЬКИХ НАВЧАЛЬНИХ ЗАНЯТТЯХ

\title{
THE PECULIARITIES OF STUDENTS' EMOTIONAL STATES IN SEMINAR CLASSES
}

УДК 159.9

DOI https://doi.org/10.32843/2663-

5208.2020.15.20

\section{Грицук О.В.}

к.психол.н., докторант кафредри

практичної психології

Харківський національний педагогічний університет імені Г.С. Сковороди
У статті здійснено аналіз особливостей емоційних станів студентів на семінарських навчальних заняттях. Виявлено міру вираженості складників емоційного стану хлопиів і дівчат на семінарських заняттях у закладах вищої освіти, порівняно вираженість самопочуття, активності й настрою студентів на семінарах у виші на різних курсах навчання. Для визначення особливостей емоційних станів студентів на семінарських навчальних заняттях використано тест диференційованої самооцінки фуннкіонального стану, розроблений В.О. Доскіним, Н.О. Лаврентьєвою, В.Б. Шарай, М.П. Мірошніковим. Застосовано t-критерій, що дав змогу порівняти середні значення кожних двох вибірок досліджуваних і зробити висновок про розрізнення двох середніх значень. Виявлено, що й у хлопців, і в дівчат самопочуття на семінарських заняттях загалом має негативні ознаки. Через високе психічне й розумове навантаження студенти відчувають себе слабкими, виснаженими, знесиленими, втомленими, млявими, сонливими, i ці відчуття статистично значущо більш виражені в дівчат, ніж у хлопців. У студентів вираженість активності на семінарських заняттях має позитивні ознаки, причому в дівчат ці показники статистично незначущо вищі, ніж у хлопців. І в хлопців, ів дівчат міра вираженості настрою на семінарських навчальних заняттях статистично значущо не відрізняється. Загалом студенти мають поганий настрій. Найнижчі показники міри самопочуття на семінарських заняттях у студентів четвертого курсу. Найви щий показник міри самопочуття спостерігається на першому курсі. Найнижчі показники міри активності на семінарських заняттях у студентів четвертого курсу, найвищі у студентів п'ятого курсу. На четвертому році навчання в них з'являються повільність, неуважність, бажання відпочити. Найвищі показники настрою на семінарських заняттях у студентів на першому курсі, найнижчі - на третьому курсі навчання.
Ключові слова: емоційний стан, семінарське навчальне заняття, самопочуття, активність, настрій, заклад вищої освіти, функціональний стан.

The article deals with the features of emotional states of students at the seminars in higher education institutions. The degree of expression of the components of the emotional states of boys and girls at the seminars is revealed. The expressiveness of well-being, activity, and mood of the students at different courses is investigated. The Test of differentiated self-assessment of functional status, developed by V.O. Doskin, N.O. Lavrentyeva, V.B. Sharay, M.P. Miroshnikov ss used to determine the characteristics of the emotional states of the students. The t-test is used to compare the average values of each of two samples of the subjects and to make a conclusion about the distinctions between them. It is found that boys and girls feel unwell at the seminars in general. Due to the high mental and intellectual load, the students are like to be weak, exhausted, exhausted, tired, lethargic, sleepy, and these feelings are statistically significantly more obvious in girls than in boys. The students have positive signs of activity at the seminars, and these indicators are statistically slightly higher in girls than in boys. The boys and girls do not have a statistically significant degree of mood expression at the seminars. In general, the students are in the bad mood. The lowest rates of well-being at the seminars have the fourthyear students. The highest rate of well-being is observed at the first year of study. The lowest rates of seminar activity have the fourth-year students and the highest rates of seminar activity have the fifth-year students. At the fourth year of study, the students reveal slowness, inattention, and a desire to relax. The highest indicators of mood at the seminars have the first-year students, the lowest indicators of mood have the third-year students.

Key words: emotional state, seminar, well-being, activity, mood, institution of higher education, functional state.
Постановка проблеми. Актуальність дослідження зумовлена тим, що емоційні стани суб'єктів освітнього процесу необхідно враховувати в методиці викладання навчальних дисциплін у закладах вищої освіти. Емоції спонукають до активності, навчальної й професійної діяльності, саморегуляції. Власне, в емоційних станах та емоціях виявляється внутрішне й зовнішнє психічне, ставлення особистості до дійсності. Викладачу важливо спостерігати за проявами емоційних процесів, переживань у студентів під час побудови ділового й особистісного спілкування в освітньому процесі.
Аналіз останніх досліджень і публікацій. Ключові проблемні питання в межах досліджень проблем емоційних станів студентів висвітлено в дослідженнях структури комплексів негативних психічних станів упродовж навчання, що залежать від індивідуальних особистісних властивостей, серед яких - низький рівень розвитку саморегуляції, несформованість її процесів, екстернальний локус контролю, низький рівень розвитку емоційного інтелекту, домінування мотивації уникнення невдач, високий рівень нейротизму, депресивності, дратівливості, сором'язливості, невротичності, агресив- 
ності, емоційної лабільності [3, с. 215]; функціонального стану студентів протягом навчання у вищому навчальному закладі, напруженість процесу навчання призводить до зменшення енергетичного потенціалу студентів [4, с. 210], зв'язку навчальної успішності й емоційного збудження на іспиті, коли неуспішні студенти характеризуються вираженими негативними емоційними станами [2, с. 127]. Виявлено, що емоційні стани, які перешкоджають ефективній роботі студентів на семінарському занятті, - це страх, шаленість, безтурботність, противність, злість, лінощі, мука, самотність, слабкість, нудьга [2, с. 125]. Уважаємо дослідження, що висвітлюють залежність емоційних станів студентів на семінарськихзаняттях залежно від статі, а також вираженість складників емоційних станів студентів залежновідкурсунавчання, актуальними.

Постановка завдання. Мета статті полягає в дослідженні особливостей емоційних станів студентів на семінарських навчальних заняттях. Це передбачає послідовне виконання таких завдань: 1) виявити міру вираженості складників емоційного стану хлопців і дівчат на семінарських заняттях у закладах вищої освіти; 2) порівняти вираженість самопочуття, активності й настрою студентів на семінарах у виші на різних курсах навчання.

Виклад основного матеріалу дослідження. Феномен емоційних станів $€$ досить різноплановим, а його структура - дискусійною, що потребує коректного методичного підходу до його вивчення. Предметом наукового інтересу $€$ особливості вираження складників емоційних станів студентів - дівчат і хлопців - залежно від курсу їх навчання. Основними складниками елементами емоційних станів $€$ самопочуття, активність, настрій. Вони характеризують як активність

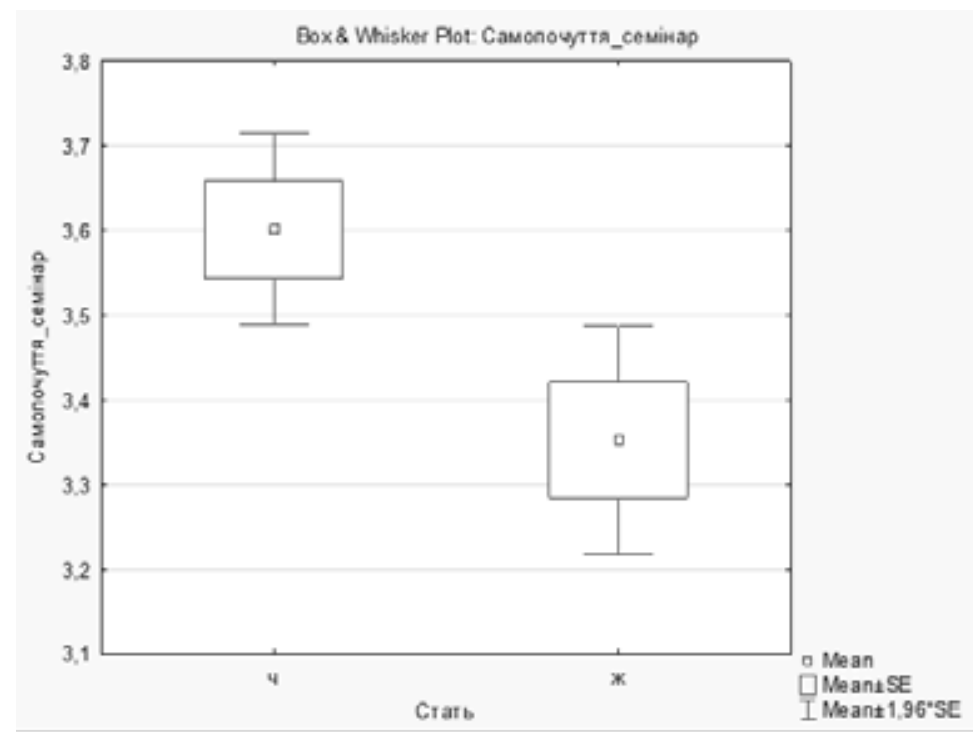

Рис. 1. Самопочуття хлопців і дівчат на семінарських навчальних заняттях психічних, соматичних, вегетативних функцій у процесі навчальної діяльності студентів, так і нейрофізіологічні механізми їхнього функціонального стану [5, с. 55].

Для визначення особливостей емоційних станів студентів на семінарських навчальних заняттях використовувався тест диференційованої самооцінки функціонального стану, розроблений В.О. Доскіним, Н.О. Лаврентьєвою, В.Б. Шарай, М.П. Мірошніковим. У дослідженні взяло участь 193 студенти вищих навчальних закладів, 108 хлопців і 85 дівчат. Отримані первинні дані оброблено за допомогою пакету STATISTICA 12.0. Застосовано t-критерій, що дав змогу порівняти середні значення кожних двох вибірок досліджуваних і зробити висновок про розрізнення двох середніх значень. Для незалежних вибірок, представники яких $€$ досліджувані студенти I-VI курсів чоловічої й жіночої статі, перевірялася достовірність розрізнень вибірок за змінною, що вимірювалася («самопочуття на семінарських навчальних заняттях», «активність на семінарських навчальних заняттях», «настрій на семінарських навчальних заняттях»), розраховувалися середні значення, за t-критерієм визначалася значущість їх розрізнень.

У таблиці 1 представлені результати дослідження міри вираженості самопочуття, активності й настрою хлопців і дівчат на лекційних навчальних заняттях.

3 представлених результатів випливає, що за показником «самопочуття» вибірка з 108 хлопців має середній бал 3,60, а вибірка із 85 жінок - середній бал 3,35 . Критерій рівності дисперсій Левіна вказує на те, що дисперсії двох розподілів мають статистично значущі розрізнення $(p=0,566580)$. За шкалою «самопочуття» відмінності між вибірками хлопців і дівчат виявлені на високому рівні статистичної значущості ( $p=0,005472)$. За показником «активність» вибірка 3 хлопців має середній бал 4,35, а вибірка з дівчат - середній бал 4,56. Критерій рівності дисперсій Левіна вказує на те, що дисперсії двох розподілів статистично значущо не розрізняються $(p=0,043568)$. За показником «настрій» вибірка з хлопців має середній бал 3,55 , а вибірка з дівчат - середній бал 3,70. Критерій рівності дисперсій Левіна вказує на те, що дисперсії двох розподілів статистично значущо не розрізняються $(p=0,008763)$.

Результати міри вираженості самопочуття хлопців і дівчат на семінарських навчальних заняттях представлені в графічному вигляді на рис. 1.

I в хлопців, і в дівчат самопочуття на семінарах загалом має негативні ознаки. Через високе психічне й розу- 
Міра вираженості самопочуття, активності й настрою хлопців і дівчат на семінарських навчальних заняттях

\begin{tabular}{|l|c|c|c|c|c|c|c|}
\hline \multirow{2}{*}{$\begin{array}{c}\text { Психоемоцій- } \\
\text { ний стан }\end{array}$} & \multicolumn{2}{|c|}{$\begin{array}{c}\text { Кількість } \\
\text { досліджуваних }\end{array}$} & \multicolumn{2}{|c|}{ Середній бал } & \multicolumn{2}{c|}{$\begin{array}{c}\text { Стандартне } \\
\text { відхилення }\end{array}$} & $\begin{array}{c}\text { Значення } \\
\text { стандартної } \\
\text { помилки }\end{array}$ \\
\cline { 2 - 8 } & чол. & жін. & чол. & жін. & чол. & жін. & 0,005472 \\
\hline Самопочуття & 108 & 85 & 3,601852 & 3,352941 & 0,594992 & 0,630681 & 0,039 \\
\hline Активність & 108 & 85 & 4,351852 & 4,564706 & 1,035039 & 0,837329 & - \\
\hline Настрій & 108 & 85 & 3,555556 & 3,705882 & 0,824092 & 1,078177 & - \\
\hline
\end{tabular}

мове навантаження студенти на семінарських заняттях відчувають себе слабкими, виснаженими, знесиленими, втомленими, млявими, сонливими, і ці відчуття статистично значущо більш виражені в дівчат, ніж у хлопців.

Результати міри вираженості активності хлопців і дівчат на семінарських навчальних заняттях представлені в графічному вигляді на рис. 2.

У студентів вираженість активності на семінарських заняттях загалом має позитивні ознаки, причому в дівчат ці показники статистично незначущо вищі, ніж у хлопців. На семінарах студенти активні, рухливі, швидкі, уважні, міркують, виконують різноманітні форми навчальної діяльності, відчувають захопленість ходом заняття, почуваються схвильовано. У них виражене бажання працювати. Швидкість і темп протікання їхніх психічних функцій мають середню міру вираженості.

Результати міри вираженості настрою хлопців і дівчат на семінарських навчальних заняттях представлені в графічному вигляді на рис. 3.

I в хлопців, і в дівчат міра вираженості настрою на семінарських навчальних заняттях статистично значущо не відрізняється. За середніми балами настрій дівчат має більш високі значення, ніж хлопців. Загалом студенти мають поганий настрій. Вони сумні, похмурі, песимістичні, почувають себе нещасливими, заклопотані різними навчальними справами, розчаровані й незадоволені власними результатами.

Семінарські заняття в закладах вищої освіти як одна з активних форм навчання [1, с. 38] мають на меті поглиблення теоретичного матеріалу, засвоєного на лекціях, самостійно тощо, його творчу й глибоку переробку. Вони можуть відбуватися у формі конференції, дискусії, бесіди, ділової гри, при цьому залучення студентів до активного диспуту $€$ однією з важливих вимог до проведення семінарських навчальних занять. На семінарі студенти розмірковують, обґрунтовують власну думку, полемізують, ставлять питання опоненту. 3 метою створення психологічної безпеки й ситуації комфорту на заняттях викладач залучає їх до дискусії та колективної роботи, запитує в них їхню думку та власне бачення будь-якої ситуації. Ці

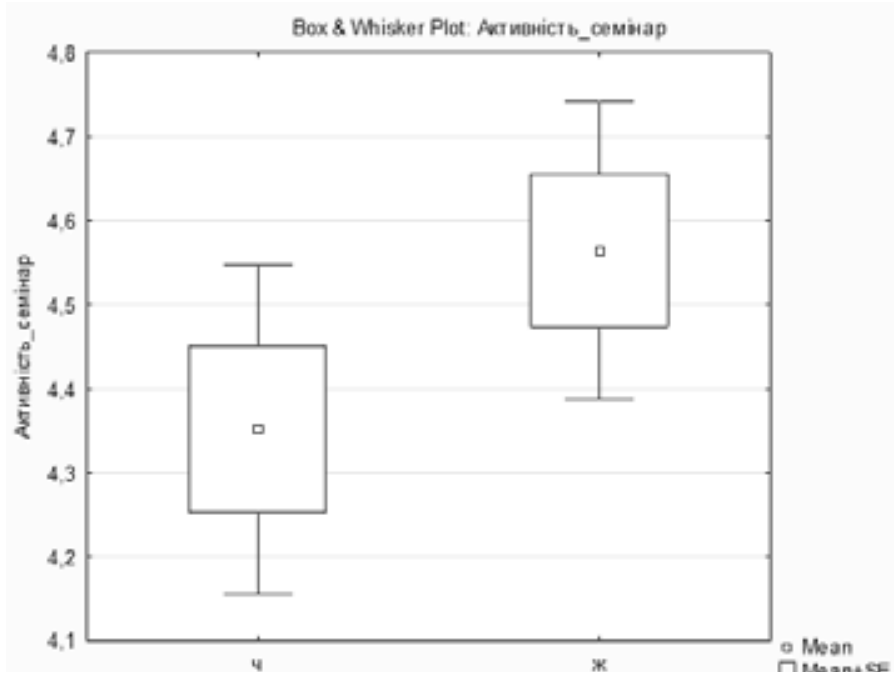

Рис. 2. Активність хлопців і дівчат на семінарських навчальних заняттях

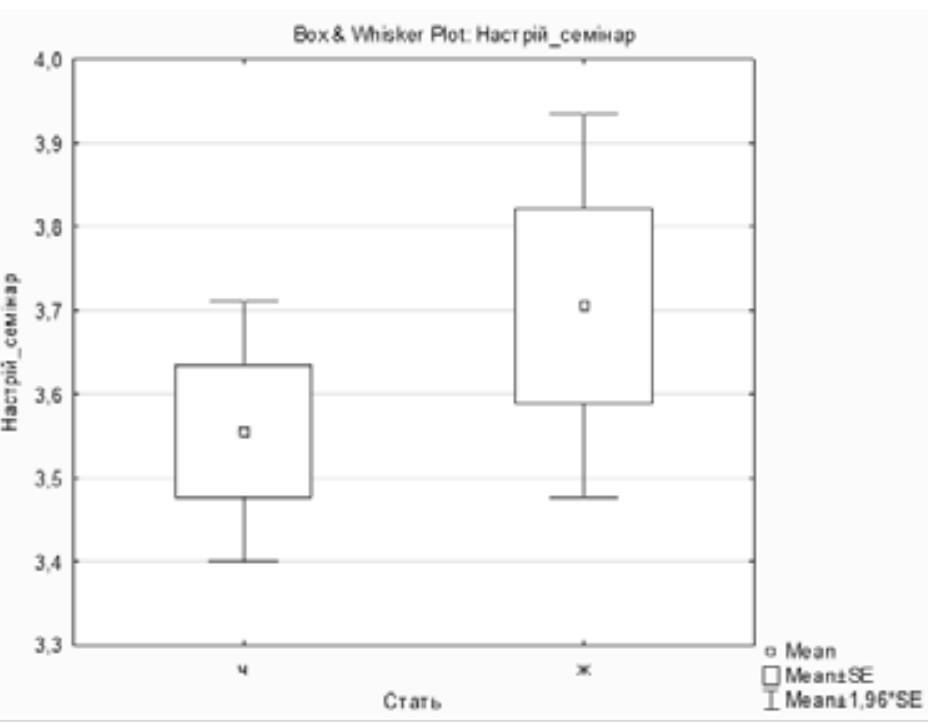

Рис. 3. Настрій хлопців і дівчат на семінарських навчальних заняттях 
форми й прийоми роботи на семінарі вимагають від студентів постійного напруження, уваги, мобілізації психічних і нервових сил, постійного чергування видів діяльності, тому вони відчувають утому, виснаження, а коли їхні очікування не збігаються з результатами навчання, ще й поганий настрій.

У таблиці 2 представлені результати дослідження міри вираженості самопочуття студентів I курсу на семінарах порівняно з II-VI курсами навчання.

Між студентами I/II, I/III, I/IV, I/V і I/IV курсів статистично значущих відмінностей у показниках міри вираженості самопочуття на семінарських заняттях не виявлено. Воно характеризується відчуттям утомленості, розсіяною увагою, безсиллям. Загалом простежується коливання міри вираженості самопочуття: після першого курсу (3,625000 \pm 0,710939) міра самопочуття на лекціях знижується на другому курсі $(3,488889 \pm 0,626034)$, на третьому зростає $(3,565217 \pm 0,506870)$, на четвертому падає $(3,416667 \pm 0,646869)$. На п'ятому $(3,454545 \pm 0,564076)$ і шостому $(3,500000 \pm 0,688247)$ курсах вона збільшується, але не перевищує показників першого курсу. Найнижчі показники міри самопочуття на семінарських заняттях у студентів четвертого курсу. Це пов'язано з великою кількістю самостійної навчальної роботи, наявністю курсових і бакалаврських робіт, коли студенти на семінарах дискутують на тему власних досліджень, обґрунтовують застосовані методи, формулюють нові ідеї. Найвищий показник міри самопочуття в студентів спостерігається на першому курсі, коли рівень дослідницької роботи й наукової відповідальності невисокий.

Таблиця 3 містить результати дослідження міри вираженості самопочуття студентів II курсу на семінарах порівняно зі студентами III-VI курсів навчання.

Виходячи з отриманих даних між показниками студентів II/III, II/IV, II/N, II/VI курсів, можемо констатувати, що статистично значущих відмінностей у показниках міри вираженості самопочуття не виявлено. Вони відчувають слабкість, виснаження, втому.

Таблиця 4 містить результати дослідження міри вираженості самопочуття студентів III курсу на семінарах порівняно зі студентами IV-VI курсів навчання.

Між показниками студентів III/IV, III/V, III/VI статистично значущих відмінностей у показниках міри вираженості самопочуття не

Таблиця 2

Міра вираженості самопочуття студентів I курсу на семінарських навчальних заняттях порівняно з II-VI курсами навчання

\begin{tabular}{|c|c|c|c|c|c|c|}
\hline \multirow{2}{*}{ Курси } & \multicolumn{2}{|c|}{ Середній бал } & \multirow[b]{2}{*}{$\mathbf{t}$} & \multicolumn{2}{|c|}{ Стандартне відхилення } & \multirow{2}{*}{$\begin{array}{l}\text { Значення стан- } \\
\text { дартної помилки }\end{array}$} \\
\hline & 1 & 2 & & 1 & 2 & \\
\hline $\mathrm{I} / \mathrm{II}$ & 3,625000 & 3,488889 & 0,820350 & 0,710939 & 0,626034 & - \\
\hline $\mathrm{I} / \mathrm{III}$ & 3,625000 & 3,565217 & 0,330648 & 0,710939 & 0,506870 & - \\
\hline $\mathrm{I} / \mathrm{IV}$ & 3,625000 & 3,416667 & 1,246388 & 0,710939 & 0,646869 & - \\
\hline I/V & 3,625000 & 3,454545 & 1,00906 & 0,710939 & 0,564076 & - \\
\hline $\mathrm{I} / \mathrm{VI}$ & 3,625000 & 3,500000 & 0,589158 & 0,710939 & 0,688247 & - \\
\hline
\end{tabular}

Таблиця 3

Міра вираженості самопочуття студентів II курсу на семінарських навчальних заняттях порівняно зі студентами III-VI курсів навчання

\begin{tabular}{|c|c|c|c|c|c|c|}
\hline \multirow{2}{*}{ Курси } & \multicolumn{2}{|c|}{ Середній бал } & \multirow{2}{*}{$\mathbf{t}$} & \multicolumn{2}{|c|}{ Стандартне відхилення } & \multirow{2}{*}{$\begin{array}{l}\text { Значення стан- } \\
\text { дартної помилки }\end{array}$} \\
\hline & 1 & 2 & & 1 & 2 & \\
\hline II/III & 3,488889 & 3,565217 & $-0,505579$ & 0,626034 & 0,506870 & - \\
\hline II/IV & 3,488889 & 3,416667 & 0,546510 & 0,626034 & 0,646869 & - \\
\hline II/V & 3,488889 & 3,454545 & 0,24945 & 0,626034 & 0,564076 & - \\
\hline $\mathrm{II} / \mathrm{VI}$ & 3,488889 & 3,500000 & $-0,064058$ & 0,626034 & 0,688247 & - \\
\hline
\end{tabular}

Таблиця 4

Міра вираженості самопочуття студентів III курсу на семінарських навчальних заняттях порівняно зі студентами IV-VI курсів навчання

\begin{tabular}{|c|c|c|c|c|c|c|}
\hline \multirow{2}{*}{ Курси } & \multicolumn{2}{|c|}{ Середній бал } & \multirow[b]{2}{*}{$\mathbf{t}$} & \multicolumn{2}{|c|}{ Стандартне відхилення } & \multirow{2}{*}{$\begin{array}{c}\text { Значення стан- } \\
\text { дартної помилки }\end{array}$} \\
\hline & 1 & 2 & & 1 & 2 & \\
\hline III/IV & 3,565217 & 3,416667 & 0,967014 & 0,506870 & 0,646869 & - \\
\hline $\mathrm{III} / \mathrm{V}$ & 3,565217 & 3,454545 & 0,75243 & 0,506870 & 0,564076 & - \\
\hline $\mathrm{III} / \mathrm{VI}$ & 3,565217 & 3,500000 & 0,35682 & 0,506870 & 0,688247 & - \\
\hline
\end{tabular}


виявлено. Вони відчувають відчуття втомленості, безсилля.

Таблиця 5 містить результати дослідження міри вираженості самопочуття студентів IV курсу на семінарах порівняно зі студентами V-VI курсів навчання.

Між показниками студентів IV/V і IV/VI статистично значущих відмінностей у показниках міри вираженості самопочуття не виявлено. Вони відчувають стан «розбитості», а також слабкість, млявість.

Таблиця 6 містить результати дослідження міри вираженості самопочуття студентів V курсу на семінарах порівняно зі студентами V курсу навчання.

Між показниками студентів V/VI статистично значущих відмінностей у показниках міри вираженості самопочуття не виявлено. Вони відчувають безсилля й виснаженість.

У таблиці 7 представлені результати дослідження міри вираженості активності студентів I курсу на семінарах порівняно зі студентами II-VI курсів навчання.

Між показниками студентів I/II, I/III, I/IV, I/V, I/VI курсів статистично значущих відмінностей у показниках міри вираженості активності не виявлено. Загалом простежується така динаміка:післяпершого курсу $(4,375000 \pm 0,875388)$ міра активності на семінарах підвищується на другому $(4,400000 \pm 1,074498)$ і третьому $(4,478261 \pm 0,790257)$ курсах, на четвер- тому курсі $(4,291667 \pm 1,051004)$ спостерігається незначне зниження, на п'ятому $(4,727273 \pm 0,839372)$ - підвищення, на шостому $(4,500000 \pm 0,888523)$ курсі навчання міра активності знижується, вона перевищує показники першого - четвертого курсів. Найнижчі показники міри активності на семінарських заняттях у студентів четвертого курсу, найвищі - у студентів п'ятого курсу. На четвертому році навчання в них з'являються повільність, неуважність, бажання відпочити. Це пов'язано з великим обсягом вимог, що пред'являються до випускника-бакалавра, а на п'ятому курсі студенти активно займаються магістерською роботою, тези якої захищають і відстоюють на семінарських навчальних заняттях тощо.

У таблиці 8 представлені результати дослідження міри вираженості активності студентів II курсу на семінарах порівняно зі студентами III-VI курсів навчання.

Між показниками студентів II/III, II/IV, II/V, II/VI курсів статистично значущих відмінностей у показниках міри вираженості активності не виявлено. Студенти на семінарах уважні, активні, рухливі, виконують багато різних видів навчальної діяльності.

У таблиці 9 представлені результати дослідження міри вираженості активності студентів III курсу на семінарах порівняно зі студентами IV-VI курсів навчання.

Таблиця 5 Міра вираженості самопочуття студентів IV курсу на семінарських навчальних заняттях порівняно зі студентами V-VI курсів навчання

\begin{tabular}{|c|c|c|c|c|c|c|}
\hline \multirow{2}{*}{ Курси } & \multicolumn{2}{|c|}{ Середній бал } & \multirow{2}{*}{$\mathbf{t}$} & \multicolumn{2}{|c|}{ Стандартне відхилення } & Значення стан- \\
\cline { 2 - 3 } & $\mathbf{1}$ & $\mathbf{2}$ & & $\mathbf{1}$ & $\mathbf{2}$ & - \\
\cline { 5 - 7 } & дартної помилки \\
\hline IV/V & 3,416667 & 3,454545 & $-0,27251$ & 0,646869 & 0,564076 & - \\
\hline IV/VI & 3,416667 & 3,500000 & $-0,475098$ & 0,646869 & 0,688247 & - \\
\hline
\end{tabular}

Таблиця 6 Міра вираженості самопочуття студентів V курсу на семінарських навчальних заняттях порівняно зі студентами VI курсу навчання

\begin{tabular}{|c|c|c|c|c|c|c|}
\hline \multirow{2}{*}{ Курси } & \multicolumn{2}{|c|}{ Середній бал } & \multirow{2}{*}{$\mathbf{t}$} & \multicolumn{2}{|c|}{ Стандартне відхилення } & \multirow{2}{*}{$\begin{array}{l}\text { Значення стан- } \\
\text { дартної помилки }\end{array}$} \\
\hline & 1 & 2 & & 1 & 2 & \\
\hline $\mathrm{V} / \mathrm{VI}$ & 3,454545 & 3,500000 & $-0,261548$ & 0,564076 & 0,688247 & - \\
\hline
\end{tabular}

Таблиця 7

Міра вираженості активності студентів I курсу на семінарських навчальних заняттях порівняно зі студентами II-VI курсів навчання

\begin{tabular}{|c|c|c|c|c|c|c|}
\hline \multirow{2}{*}{ Курси } & \multicolumn{2}{|c|}{ Середній бал } & \multirow{2}{*}{$\mathbf{t}$} & \multicolumn{2}{|c|}{ Стандартне відхилення } & \multirow{2}{*}{$\begin{array}{l}\text { Значення стан- } \\
\text { дартної помилки }\end{array}$} \\
\hline & 1 & 2 & & 1 & 2 & \\
\hline $1 / I I$ & 4,375000 & 4,400000 & $-0,097872$ & 0,875388 & 1,074498 & - \\
\hline $\mathrm{I} / \mathrm{III}$ & 4,375000 & 4,478261 & $-0,423883$ & 0,875388 & 0,790257 & - \\
\hline I/IV & 4,375000 & 4,291667 & 0,334430 & 0,875388 & 1,051004 & - \\
\hline $\mathrm{I} / \mathrm{V}$ & 4,375000 & 4,727273 & $-1,53650$ & 0,875388 & 0,839372 & - \\
\hline $\mathrm{I} / \mathrm{VI}$ & 4,375000 & 4,500000 & $-0,468440$ & 0,875388 & 0,888523 & - \\
\hline
\end{tabular}


Міра вираженості активності студентів II курсу на семінарських навчальних заняттях порівняно зі студентами III-VI курсів навчання

\begin{tabular}{|c|c|c|c|c|c|c|}
\hline \multirow{2}{*}{ Курси } & \multicolumn{2}{|c|}{ Середній бал } & \multirow{2}{*}{ t } & \multicolumn{2}{|c|}{ Стандартне відхиення } & \begin{tabular}{c} 
Значення стан- \\
\cline { 2 - 3 } \\
\cline { 2 - 3 } дартної помилки
\end{tabular} \\
\hline II / III & $\mathbf{1}$ & $\mathbf{2}$ & & $\mathbf{1}$ & $\mathbf{2}$ & - \\
\hline II / IV & 4,400000 & 4,478261 & $-0,308760$ & 1,074498 & 0,790257 & - \\
\hline II / V & 4,400000 & 4,291667 & 0,491414 & 1,074498 & 1,051004 & - \\
\hline II / VI & 4,400000 & 4,500000 & $-0,364101$ & 1,074498 & 0,888523 & - \\
\hline
\end{tabular}

Таблиця 9

Міра вираженості активності студентів III курсу на семінарських навчальних заняттях порівняно зі студентами IV-VI курсів навчання

\begin{tabular}{|c|c|c|c|c|c|c|}
\hline \multirow{2}{*}{ Курси } & \multicolumn{2}{|c|}{ Середній бал } & \multirow[b]{2}{*}{$\mathbf{t}$} & \multicolumn{2}{|c|}{ Стандартне відхилення } & \multirow{2}{*}{$\begin{array}{c}\text { Значення стан- } \\
\text { дартної помилки }\end{array}$} \\
\hline & 1 & 2 & & 1 & 2 & \\
\hline $\mathrm{III} / \mathrm{IV}$ & 4,478261 & 4,291667 & 0,754295 & 0,790257 & 1,051004 & - \\
\hline III/V & 4,478261 & 4,727273 & $-1,11836$ & 0,790257 & 0,839372 & - \\
\hline $\mathrm{III} / \mathrm{VI}$ & 4,478261 & 4,500000 & $-0,08493$ & 0,790257 & 0,888523 & - \\
\hline
\end{tabular}

Таблиця 10

Міра вираженості активності студентів IV курсу на семінарських навчальних заняттях порівняно зі студентами V-VI курсів навчання

\begin{tabular}{|c|c|c|c|c|c|c|}
\hline \multirow{2}{*}{ Курси } & \multicolumn{2}{|c|}{ Середній бал } & \multirow{2}{*}{ t } & Стандартне відхилення & Значення стан- \\
\cline { 2 - 3 } \cline { 5 - 6 } & $\mathbf{1}$ & $\mathbf{2}$ & & $\mathbf{1}$ & $\mathbf{2}$ & дартної помилки \\
\hline $\mathrm{IV} / \mathrm{V}$ & 4,291667 & 4,727273 & $-1,98415$ & 1,051004 & 0,839372 & - \\
\hline $\mathrm{IV} / \mathrm{VI}$ & 4,291667 & 4,500000 & $-0,777400$ & 1,051004 & 0,888523 & - \\
\hline
\end{tabular}

Таблиця 11

Міра вираженості активності студентів V курсу на семінарських навчальних заняттях порівняно зі студентами VI курсу навчання

\begin{tabular}{|c|c|c|c|c|c|c|}
\hline \multirow{2}{*}{ Курси } & \multicolumn{2}{|c|}{ Середній бал } & \multirow{2}{*}{ t } & \multicolumn{2}{|c|}{ Стандартне відхилення } & Значення стан- \\
\cline { 2 - 3 } & $\mathbf{1}$ & $\mathbf{2}$ & & $\mathbf{1}$ & $\mathbf{2}$ & дартної помилки \\
\hline $\mathrm{V} / \mathrm{Vl}$ & 4,727273 & 4,500000 & 0,934733 & 0,839372 & 0,888523 & - \\
\hline
\end{tabular}

Таблиця 12

Міра вираженості настрою студентів I курсу на семінарських навчальних заняттях порівняно зі студентами II-VI курсів навчання

\begin{tabular}{|c|c|c|c|c|c|c|}
\hline \multirow{2}{*}{ Курси } & \multicolumn{2}{|c|}{ Середній бал } & \multirow{2}{*}{$\mathbf{t}$} & \multicolumn{2}{|c|}{ Стандартне відхиення } & Значення стан- \\
\cline { 2 - 3 } \cline { 5 - 6 } дартної помилки
\end{tabular}

Таблиця 13

Міра вираженості настрою студентів II курсу на семінарських навчальних заняттях порівняно зі студентами III-VI курсів навчання

\begin{tabular}{|c|c|c|c|c|c|c|}
\hline \multirow{2}{*}{ Курси } & \multicolumn{2}{|c|}{ Середній бал } & \multirow{2}{*}{ t } & \multicolumn{2}{c|}{ Стандартне відхилення } & $\begin{array}{c}\text { Значення стан- } \\
\text { дартної помилки }\end{array}$ \\
\cline { 2 - 3 } & $\mathbf{1}$ & $\mathbf{2}$ & & $\mathbf{1}$ & $\mathbf{2}$ & - \\
\hline II/III & 3,688889 & 3,434783 & 1,171084 & 0,924962 & 0,662371 & - \\
\hline II/IV & 3,688889 & 3,541667 & 0,658760 & 0,924962 & 1,202096 & - \\
\hline II/V & 3,688889 & 3,666667 & 0,10825 & 0,924962 & 0,853913 & - \\
\hline II/VI & 3,688889 & 3,700000 & $-0,044722$ & 0,924962 & 0,923381 & \\
\hline
\end{tabular}


Між показниками студентів III/IV, III/N, III/VI курсів статистично значущих відмінностей у показниках міри вираженості активності не виявлено. Студенти розмірковують, висувають гіпотези, перевіряють їх, роблять висновки.

У таблиці 10 представлені результати дослідження міри вираженості активності студентів IV курсу на семінарах порівняно зі студентами V-VI курсів навчання.

Між показниками студентів IV/V, IV/VI курсів статистично значущих відмінностей у мірі вираженості активності не виявлено. Вони випробовують захопленість ходом навчальної діяльності, хочуть працювати на семінарах.

У таблиці 11 представлені результати дослідження міри вираженості активності студентів V курсу на семінарських заняттях порівняно зі студентами VI курсу навчання.

Між показниками студентів V/VI курсів статистично значущих відмінностей у мірі вираженості активності не виявлено. Вони активні, схвильовані, захоплені.

У таблиці 12 представлені результати дослідження міри вираженості настрою студентів I курсу на семінарах порівняно зі студентами II-VI курсів навчання.

Між показниками студентів I/II, I/III, I/IV, I/V, I/VI курсів статистично значущих відмінностей упоказникахміривираженостінастроюневиявлено. Загалом простежується така динаміка: після першого курсу $(3,708333 \pm 0,806450)$ міра настрою на семінарах статистично незначущо знижується на другому $(3,688889 \pm 0,924962)$ і третьому $(3,434783 \pm 0,662371)$ курсах, із четвертого $(3,541667 \pm 1,202096)$, п'ятого
$(3,666667 \pm 0,853913)$ і до шостого $(3,700000 \pm$ 0,923381) курсів спостерігається незначне підвищення міри вираженості настрою в студентів, що досягає рівня першого курсу навчання. Найвищі показники настрою на семінарських заняттях у студентів на першому курсі, найнижчі - на третьому курсі навчання. Хвилювання, похмурий настрій, заклопотаність, пов'язані з початком першої сходинки в отриманні вищої освіти. Песимізм, поганий настрій на третьому курсі пов'язані з великою кількістю складних навчальних завдань дослідницького типу й самостійністю в наукових пошуках.

У таблиці 13 представлені результати дослідження міри вираженості настрою студентів II курсу на семінарах заняттях порівняно зі студентами III-VI курсів навчання.

Між показниками студентів II/III, II/IV, II/N, II/VI курсів статистично значущих відмінностей у показниках міри вираженості настрою не виявлено. Спостерігаються незначні коливання настрою з його максимальним піднесенням на шостому курсі, але показники настрою свідчать про те, що студенти відчувають незадоволення й розчарування результатами навчальної діяльності.

У таблиці 14 представлені результати дослідження міри вираженості настрою студентів III курсу на семінарах заняттях порівняно зі студентами IV-VI курсів навчання.

Між показниками студентів III/IV, III/V, III/VI курсів статистично значущих відмінностей у показниках міри вираженості настрою не виявлено. 3 третього до четвертого курсів

Міра вираженості настрою студентів III курсу на семінарських навчальних заняттях порівняно з IV-VI курсів навчання

\begin{tabular}{|c|c|c|c|c|c|c|}
\hline \multirow{2}{*}{ Курси } & \multicolumn{2}{|c|}{ Середній бал } & \multirow{2}{*}{$\mathbf{t}$} & \multicolumn{2}{|c|}{ Стандартне відхилення } & \multirow{2}{*}{$\begin{array}{l}\text { Значення стан- } \\
\text { дартної помилки }\end{array}$} \\
\hline & 1 & 2 & & 1 & 2 & \\
\hline III/IV & 3,434783 & 3,541667 & $-0,397511$ & 0,662371 & 1,202096 & - \\
\hline $\mathrm{III} / \mathrm{V}$ & 3,434783 & 3,666667 & $-1,09228$ & 0,662371 & 0,853913 & - \\
\hline $\mathrm{III} / \mathrm{VI}$ & 3,434783 & 3,700000 & $-1,09242$ & 0,662371 & 0,923381 & - \\
\hline
\end{tabular}

Таблиця 15

Міра вираженості настрою студентів IV курсу на семінарських навчальних заняттях порівняно зі студентами V-VI курсів навчання

\begin{tabular}{|c|c|c|c|c|c|c|}
\hline \multirow{2}{*}{ Курси } & \multicolumn{2}{|c|}{ Середній бал } & \multirow{2}{*}{ t } & \multicolumn{2}{c|}{ Стандартне відхилення } & Значення стан- \\
\cline { 2 - 3 } & $\mathbf{1}$ & $\mathbf{2}$ & & $\mathbf{1}$ & $\mathbf{2}$ & дартної помилки \\
\hline IV/V & 3,541667 & 3,666667 & $-0,51433$ & 1,202096 & 0,853913 & - \\
\hline IV/VI & 3,541667 & 3,700000 & $-0,526968$ & 1,202096 & 0,923381 & - \\
\hline
\end{tabular}

Таблиця 16

Міра вираженості настрою студентів V курсу на семінарських навчальних заняттях порівняно зі студентами VI курсу навчання

\begin{tabular}{|c|c|c|c|c|c|c|}
\hline \multirow{2}{*}{ Курси } & \multicolumn{2}{|c|}{ Середній бал } & \multirow{2}{*}{$\mathbf{t}$} & \multicolumn{2}{|c|}{ Стандартне відхилення } & \begin{tabular}{c} 
Значення стан- \\
\cline { 2 - 3 }
\end{tabular} \\
\cline { 2 - 3 } & $\mathbf{1}$ & $\mathbf{2}$ & & $\mathbf{1}$ & $\mathbf{2}$ & - \\
\hline $\mathrm{V} / \mathrm{Vl}$ & 3,666667 & 3,700000 & $-0,133603$ & 0,853913 & 0,923381 & помилки \\
\hline
\end{tabular}


міра позитивного настрою в студентів статистично незначущо підвищується.

У таблиці 15 представлені результати дослідження міри вираженості настрою студентів IV курсу на семінарах заняттях порівняно зі студентами V-VI курсів навчання.

Між показниками студентів IV/V, IV/VI курсів статистично значущих відмінностей у показниках міри вираженості настрою не виявлено. 3 четвертого до шостого курси міра позитивного настрою поступово підвищується.

У таблиці 16 представлені результати дослідження міри вираженості настрою студентів $\checkmark$ курсу на семінарських заняттях порівняно зі студентами VI курсу навчання.

Між показниками студентів V/VI курсів статистично значущих відмінностей у показниках міри вираженості настрою не виявлено. 3 п'ятого до шостого курси міра позитивного настрою підвищується.

Отже, визначено, що й у хлопців, і в дівчат самопочуття на семінарських заняттях загалом має негативні ознаки. Через високе психічне й розумове навантаження студенти відчувають себе слабкими, виснаженими, знесиленими, втомленими, млявими, сонливими, і ці відчуття статистично значущо більш виражені в дівчат, ніж у хлопців. У студентів вираженість активності на семінарських заняттях має позитивні ознаки, причому в дівчат ці показники статистично незначущо вищі, ніж у хлопців. На семінарах студенти активні, рухливі, швидкі, уважні, міркують, виконують різноманітні форми навчальної діяльності, відчувають захопленість ходом заняття, почуваються схвильовано. I в хлопців, і в дівчат міра вираженості настрою на семінарських навчальних заняттях статистично значущо не відрізняється. Загалом студенти мають поганий настрій. Вони сумні, похмурі, песимістичні, почувають себе нещасливими, заклопотані різними навчальними справами, розчаровані й незадоволені власними результатами. Найнижчі показники міри самопочуття на семінарських заняттях у студентів четвертого курсу. Найвищий показник міри самопочуття спостерігається на першому курсі, коли рівень дослідницької роботи й наукової відповідальності невисокий. Найнижчі показники міри активності на семінарських заняттях у студентів четвертого курсу, найвищі - у студентів п'ятого курсу. На четвертому році навчання в них 3'являються повільність, неуважність, бажання відпочити. Це пов'язано з великим обсягом вимог, що пред'являються до випускника-бакалавра, а на п'ятому курсі студенти активно займаються магістерською роботою, тези якої захищають і відстоюють на семінарських навчальних заняттях тощо. Найвищі показники настрою на семінарських заняттях у студентів на першому курсі, найнижчі - на третьому курсі навчання. Хвилювання, похмурий настрій, заклопотаність пов'язані з початком першої сходинки в отриманні вищої освіти.

Висновки 3 проведеного дослідження. Підсумовуючи, зазначимо, що загалом у студентів самопочуття на семінарських заняттях має негативні риси. Вираженість активності на семінарах має позитивні ознаки, причому в дівчат ці показники статистично незначущо вищі, ніж у хлопців. I в хлопців, і в дівчат міра вираженості настрою на семінарських навчальних заняттях статистично значущо не відрізняється: студенти мають поганий настрій. Найнижчі показники міри самопочуття на семінарських заняттях у студентів четвертого курсу. Найвищий показник міри самопочуття спостерігається на першому курсі. Найнижчі показники міри активності на семінарських заняттях у студентів четвертого курсу, найвищі - у студентів п'ятого курсу. Найвищі показники настрою на семінарських заняттях у студентів на першому курсі, найнижчі - на третьому курсі навчання.

Перспективою дослідження є порівняльний аналіз емоційних станів студентів на лекціях, семінарах і лабораторних заняттях.

\section{ЛІТЕРАТУРА:}

1. Абрамян Н.Г., Пронина Е.В. Методика преподавания психологии. Владимир : Изд-во ВлГУ, 2017. 82 с.

2. Діомідова Н.Ю. Психічні стани успішних та неуспішних студентів у ситуації іспиту. Психологія і особистість. 2016. № 1 (9). С. 119-128.

3. Ігумнова О.Б. Модель та програма психокорекції негативних психічних станів студентів ВН3. Вiсник Національного університету оборони України. 2013. № 5 (36). C. 215-221.

4. Лис Ю.С. Дослідження фрункціонального стану студентів у процесі навчання. Збірник наукових праць Харківського університету Повітряних Сил. 2016. № 3 (48). C. 208-211.

5. Машин В.А. К вопросу классификации фрункциональных состояний человека. Экспериментальная психология. 2011. Том 4. № 1. С. 40-56. 